\title{
Arsenic concentrations in the San Pedro River of Chihuahua, Mexico
}

\author{
R. Gutiérrez-Espinoza ${ }^{1}$, H. Rubio-Arias ${ }^{2}$, R. Quintana ${ }^{1}$, \\ J. A. Ortega ${ }^{1} \&$ C. Pinedo ${ }^{1}$ \\ ${ }^{I}$ Faculty of Zootechnic, Autonomous University of Chihuahua, Mexico \\ ${ }^{2}$ Experimental Research Center La Campana-Madera, INIFAP, Mexico
}

\begin{abstract}
There is a general belief that high levels of arsenic are found in waters of the northern states of Mexico. In order to test this hypothesis, research was conducted with the objective of determining arsenic levels in waters of the San Pedro River located in the state of Chihuahua, Mexico. From October 2005 to August 2006 on a monthly basis, water samples were collected at five points along the San Pedro River. Three repetitions were collected at each point resulting in a total of 165 water samples. Total arsenic concentration was $\mathrm{L}^{-1}$ detected in an Inductively Coupled Plasma-Optical Emission Spectrometer (ICPPOE) model 2100 by Perkin Elmer. The arsenic concentrations in waters of the San Pedro River ranged from $0.0110 \mathrm{mg} \mathrm{L}^{-1}$ to $0.587 \mathrm{mg} \mathrm{L}^{-1}$ with a mean of $0.104 \mathrm{mg} \mathrm{L}^{-1} \pm 0.234 \mathrm{mg}$. Most samples were over the maximum permissible value established as Mexican and international standards. A quadratic projection was observed between the basic points through the fifth point; these results might be influenced by the decrease of flow and the decrease of the drainage level. These results confirm the hypothesis that waters in northern Mexico contain high levels of arsenic that potentially might be harmful to the whole ecosystem and being potentially dangerous to human development and health. Keywords: arsenic, Chihuahua, Mexico, San Pedro, pollution.
\end{abstract}

\section{Introduction}

Arsenic (As) is a metalloid generally considered toxic that may be present in a variety of water environments. This metalloid is ubiquitous, meaning that it may be found in air [1], water [2,3], soil [4], plants [5], as well as in other living 
organisms [6]. This elements is considered teratogenic [7], carcinogenic [8,9] and has been associated with different diseases $[10,11]$. An extreme case is Bangladesh were millions people drink water with an arsenic concentration higher than $10 \mu \mathrm{g} \mathrm{L}^{-1}$ that is much higher than the guidelines recommended by the World Health Organization [12]. Moreover, recent research has hypothesized that the ingestion of arsenic by humans has been associated with the potential increase of Type 2 diabetes in inhabitants living in high-arsenic areas [13-15]; nonetheless, in other studies carried out in the United States this effect has not been proven [16]. The good news concerning this element is that some arsenic compounds might be positively utilized to treat some kinds of leukaemia [17] and that there is no evidence of food chain biomagnification [18].

Among the inhabitants of northern Mexico, the word arsenic is considered synonymous with the word poison. In addition, there is a general believe that waters contains high levels of this element. Even though there are some studies in Mexico that show different levels of arsenic in a variety of water environments $[19,20]$, no information is available concerning levels of arsenic in the San Pedro River. The San Pedro River is one tributary of the Conchos River that is considered the most important for the inhabitants of the state of Chihuahua. Along the San Pedro River there are several communities that have experienced unprecedented human development as a result of industrial, agricultural and livestock activities.

For this reason it is important to know the water quality that flows in this river. Therefore, the objective was to determine the arsenic levels in the water of the San Pedro River located in the state of Chihuahua, Mexico. The results will shed light on the potential effects of arsenic in the health of the inhabitants settled along the river, as well as to give an idea about the toxic levels for the whole environment.

\section{Materials and methods}

The research was carried out from October 2005 to August 2005. Five points along the San Pedro River were located to collect a monthly water sample (Figure 1). The locations were; La Presa, Rosales, Meoqui, El Torreon and La junta de los Rios. The water samples were collected monthly from October 2005 through August 2006. Three water repetitions were obtained; hence, a total of 165 water samples were collected for the whole study.

The water samples were collected in polyethylene bottles that were previously rinsed with nitric acid and deionised water. Once the water samples were collected, they were placed in an ice box to be transported to the laboratory of the Faculty of Zootechnic of the Autonomous University of Chihuahua where they were placed at about $4^{\circ} \mathrm{C}$. Arsenic extraccion was done according to the Mexican Norm [21] using nitric acid digestion. Arsenic concentration levels were measured using an Inductively Coupled Plasma-Optical Emission Spectrometry (ICP-OES) Perkin Elmer 2100 property of the laboratory of the National Research Institute for Forestry, Agriculture and Livestock in Chihuahua, Mexico. 
The results were compared with some Mexican standards, with the U.S. Environmental Protection Agency (EPA) and some standards and reference doses for humans (EPA). Two probability graphs were designed to show confidence intervals considering monthly samples as well as locations samples.

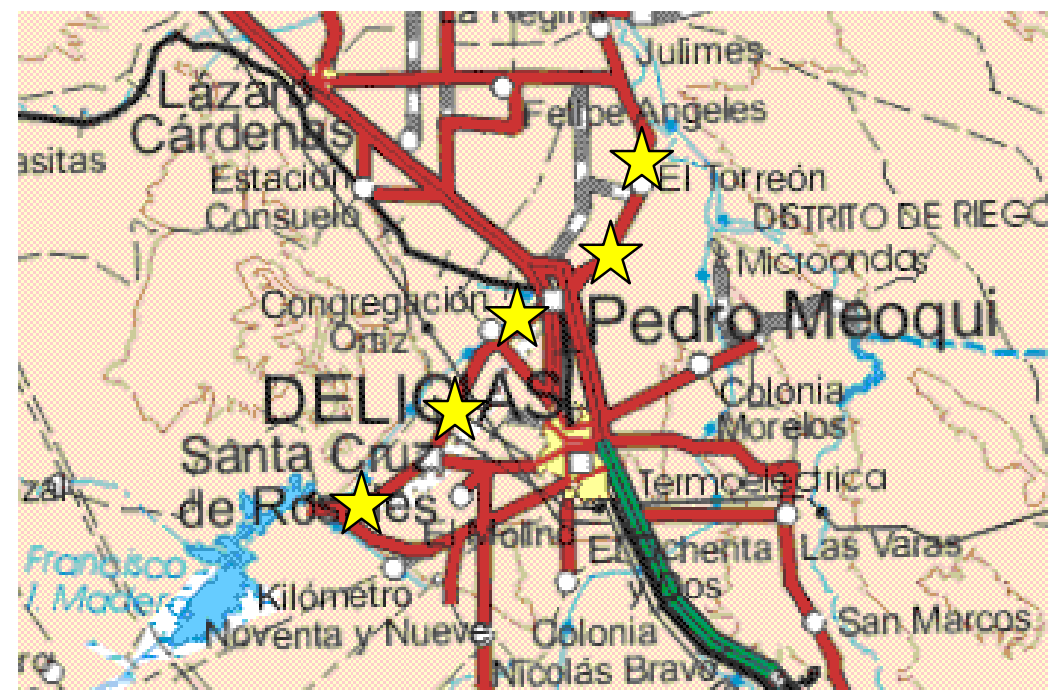

Figure 1: Sampling points in the San Pedro River to estimate arsenic pollution.

\section{Results and discussion}

The samples collected in October 2005 resulted in a concentration of $0.08 \mathrm{mg} \mathrm{L}^{-1}$ for La Presa, $0.11 \mathrm{mg} \mathrm{L}^{-1}$ for Rosales, $0.13 \mathrm{mg} \mathrm{L}^{-1}$ for Meoqui, $0.15 \mathrm{mg} \mathrm{L}^{-1}$ for El Torreon and $0.14 \mathrm{mg} \mathrm{L}^{-1}$ in Junta de los Rios. It can be noted an increase of the arsenic concentration as the water flows down from the upper part (La Presa location) to the lower part (Junta de los Rios). The concentrations of all samples in the five locations were higher than the values specified in the Mexican Norm $\left(0.01 \mathrm{mg} \mathrm{L}^{-1}\right)$ as well as the EPA for potable water $\left(0.01 \mathrm{mg} \mathrm{L}^{-1}\right)$. In addition, the concentration values of four locations were higher than the values established in the Mexican Norm for agricultural uses $\left(0.10 \mathrm{mg} \mathrm{L}^{-1}\right)$. The second sample of November 2005 resulted in lower concentrations of arsenic in the five locations as compared with the October samples. Hence, the result for La Presa was 0.10 $\mathrm{mg} \mathrm{L}^{-1}$, for Rosales $0.07 \mathrm{mg} \mathrm{L}^{-1}$, for Meoqui, $0.07 \mathrm{mg} \mathrm{L}^{-1}$, for El Torreon 0.04 $\mathrm{mg} \mathrm{L}^{-1}$ and a concentration of $0.05 \mathrm{mg} \mathrm{L}^{-1}$ in Junta de los Rios. All samples were higher than the values of the Mexican Norm as well as those established in the International standards for potable water. The third sample collected in December 2005 resulted in the following concentrations: $0.03 \mathrm{mg} \mathrm{L}^{-1}$ in $\mathrm{La}$ Presa, $0.06 \mathrm{mg} \mathrm{L}^{-1}$ in Rosales, $0.09 \mathrm{mg} \mathrm{L}^{-1}$ in Meoqui, $0.05 \mathrm{mg} \mathrm{L}^{-1}$ in El Torreon and $0.07 \mathrm{mg} \mathrm{L}^{-1}$ in Junta de los Rios. 
The results of the arsenic concentration in the waters of San Pedro River at five locations in the State of Chihuahua, Mexico during 2006 are shown in Table 1. In general, the location La Presa was less contaminated compared with the other four sampled locations. The maximum concentration over the whole study was noted in March on El Torreon with $0.2533 \mathrm{mg} \mathrm{L}^{-1}$. This concentration is much higher that that established in the Mexican Norm for waters used in agriculture $\left(0.10 \mathrm{mg} \mathrm{L}^{-1}\right)$ and for livestock production $\left(0.20 \mathrm{mg} \mathrm{L}^{-1}\right)$. With a few exceptions, the results are higher than the values indicated in Mexican and International Norms for potable water.

Although the inhabitants settled in communities close to the river did not drink water directly, the use of such water is common for different activities especially in rural areas. These findings must be an alert to the people living in the area or close to the area, because the arsenic was considered an important element in the development of leukemia [22] that was detected in an abnormally large number of children if Nevada, USA [23].

Table 1: $\quad$ Mean concentration of arsenic in five locations of the San Pedro River during the 2006 sampling $\left(\mathrm{mg} \mathrm{L}^{-1}\right)$.

\begin{tabular}{|l|l|l|l|l|l|l|l|l|}
\hline Location & January & Feb & March & April & May & June & July & August \\
\hline La Presa & 0.0726 & 0.0633 & 0.0753 & 0.0766 & 0.0736 & 0.0920 & 0.1353 & 0.0376 \\
\hline Rosales & 0.1213 & 0.0740 & 0.1370 & 0.1130 & 0.1320 & 0.1123 & 0.1246 & 0.0860 \\
\hline Meoqui & 0.0923 & 0.1100 & 0.1343 & 0.1106 & 0.1316 & 0.1396 & 0.1536 & 0.1436 \\
\hline $\begin{array}{l}\text { El } \\
\text { Torreon }\end{array}$ & 0.1163 & 0.1260 & 0.2533 & 0.1246 & 0.1156 & 0.1333 & 0.1143 & 0.0916 \\
\hline $\begin{array}{l}\text { Junta de } \\
\text { los Rios }\end{array}$ & 0.1160 & 0.1183 & 0.1616 & 0.0940 & 0.1380 & 0.1263 & 0.0903 & 0.0933 \\
\hline
\end{tabular}

It is recognized that arsenic is primarily released into water due to intemperism of soil and rocks as well as from geothermal sources [24]. The other source is from anthropogenic activities mainly agricultural applications [25]. These findings did not find evidence of anthropogenic sources in the water of the San Pedro River and agree with results of previous studies in a tributary close to the San Pedro River [20]. These researchers found an arsenic range of 19.7-60.0 $\mathrm{mg} \mathrm{L}^{-1}$ in three segments of the Rio Conchos.

Even though the arsenic concentrations in the waters of the San Pedro River apparently are not of human concern because it is not drank directly, the results reported here might be considered an alert for the aquatic environment when it is considered that Cantu et al., [26] reported that large-mouth bass (Micropterus salmoides) had deformed fins, jaws heads and eyes in a water environment with $0.54 \mathrm{mg} \mathrm{L}^{-1}$. In addition, the ambient water quality criteria for arsenic for protection of human health have been established at a safe level of $0.14 \mu \mathrm{g} \mathrm{L}^{-1}[27]$.

The results in this study were much higher than this specific value. It should be noted that people living in the communities along the San Pedro River consume fish collected from the river, and there is no information about the level of contamination in edible tissues of these fish. Finally, the other concern that should be evaluated for the San Pedro River is the water quality supplied for the 
wells that are in operation for human needs. This is important because there are evidences that the groundwaters in the aquifer of that area have arsenic levels that are higher than the levels permitted in Mexican and International norms [28].

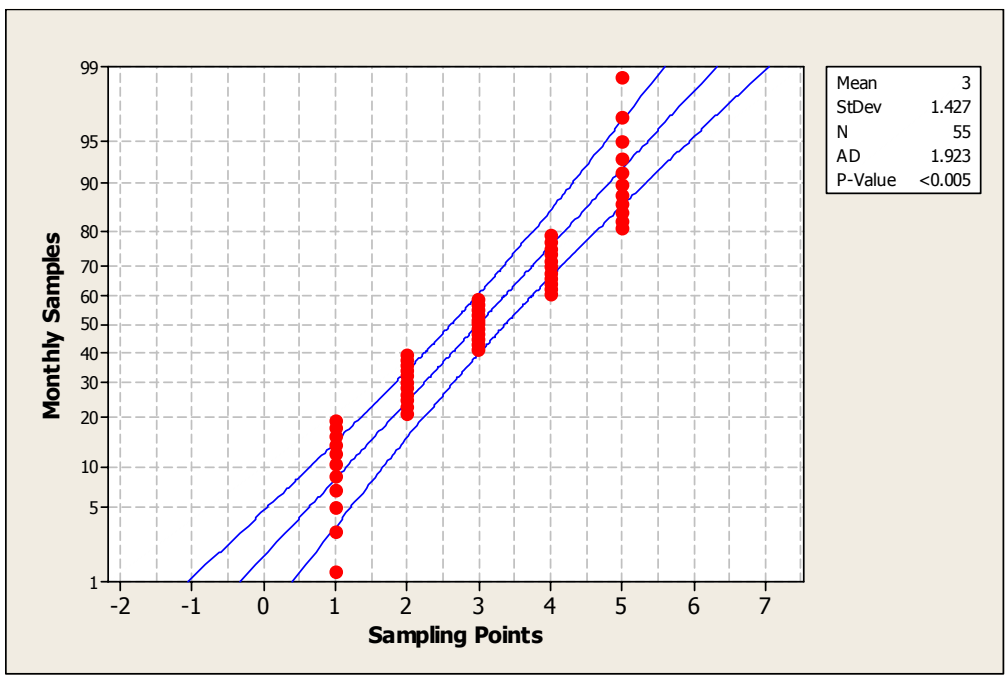

Figure 2: A 95\% Confidence Intervals of the arsenic concentration in five sampling points in the San Pedro River in Chihuahua, Mexico.

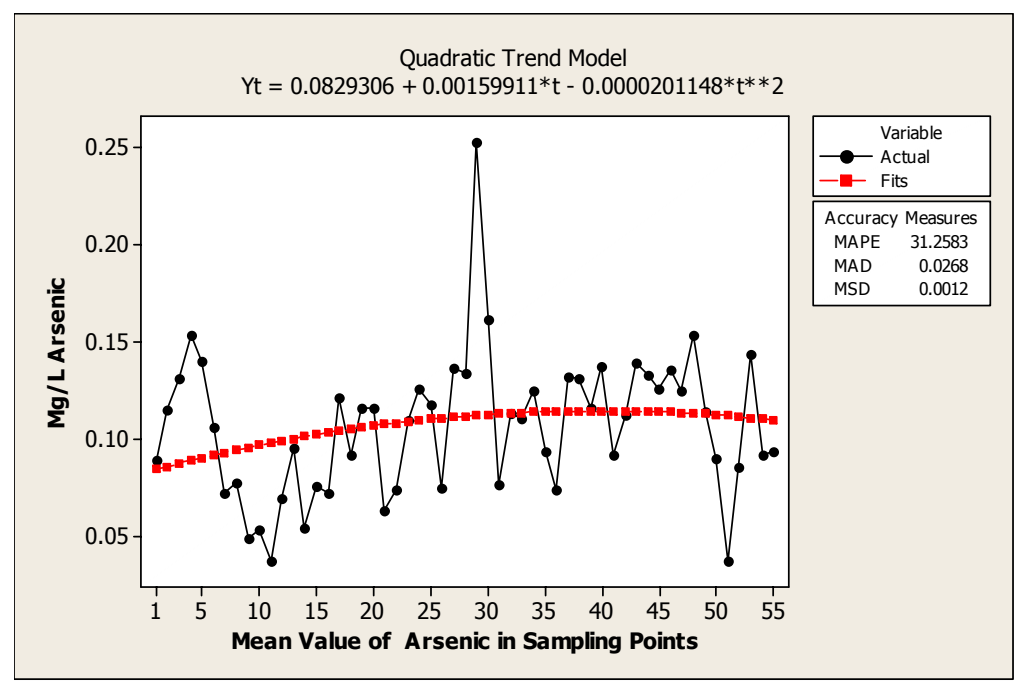

Figure 3: Quadratic trend of the arsenic concentration in the San Pedro River in Chihuahua, Mexico. 
In Figure 2 the Confidence Intervals are shown for the five sampling locations in a monthly period. Moreover, in Figure 3 it is noted a quadratic trend in the different locations as well as the monthly samples concerning the arsenic concentration in the San Pedro River.

\section{Conclusions}

The data obtained in this study confirm our hypothesis that waters of the San Pedro River contain arsenic levels that are above levels recommended for Mexican as well as international standards. Therefore, we suggest future studies concerning the effects of these arsenic levels on human health and ecosystem effects, and especially to determine if arsenic pollution is due to natural or anthropogenic sources.

\section{References}

[1] Chu-Fang, Wang, Cheng-Yuan, Ch., Su-Fen, T., \& Hung-Lung, Ch. 2005. Characteristics of Road Dust from Different Sampling Sites in Northern Taiwan. Journal of the Air \& Waste Management Association 55(8):12361244

[2] Rubio, A.H., Wood, K., \& Alanis, H.E. 2004. Water pollution in the Rio Conchos of northern Mexico. Development and application of computer technics to Environmental studies X. Ed. G. Latini, G. Passerini, and C.A. Brebbia. Wit press. 167-176.

[3] Rubio, A.H., Saucedo, T.R., Lara, M.C., Wood, K., \& Jimenez, J. 2005. Water quality in the Laguna de Bustillos of Chihuahua, Mexico. Water Resources Management III. Ed. M. de Conceicao Cunha and C.A. Brebbia. Wit press. 155-160

[4] Rubio, A.H., Saucedo, T.R., Wood, K., Nuñez, A., \& Jimenez, J. 2005. Metal contamination of a riparian area in the conchos watershed of Chihuahua, Mexico. Water Resources Management III. Ed. M. de Conceicao Cunha and C.A. Brebbia. Wit press. 269-275

[5] Prasad, M.N.V. \& de Oliveira Freitas, H.M. 2003. Metal hyperaccumulation in plants-Biodiversity prospecting for phytoremediation technology. Electron. J. Biatechnol. 6, 285-321.

[6] Baos, R., Blas, J., Bortolotti, G.R., Marchant, T.A., \& Hiraldo, F. 2006. Adrenocortical Response to Stress and Thyroid Hormone Status in FreeLiving Nestling White Storks (Ciconia ciconia) Exposed to Heavy Metal and Arsenic Contamination. Environmental Health Perspectives 114(10):1497-1501

[7] WHO. 2001. Arsenic and Arsenic Compounds. Environmental Health Criteria 224. 2nd ed. Geneva: World Health Organization. Available: http://www.who.int/ipcs/publications/ehc/ ehc_224/en/ [accessed 10 February 2007.

[8] Chen, C.J., Kuo, T.L., \& Wu, M.M. 1988. Arsenic and cancer. Lancet 1: 414-415 
[9] IARC, 2004. International Agency for Research on Cancer. Some Drinking-Water Disinfectants and Contaminants, Including Arsenic. IARC Monogr Eval Carcinog Risks Hum 84.

[10] Hopenhayn-Rich, C., Biggs, \& M.C., Smith, A.H. 1998. Lung and kidney cancer mortality associated with arsenic in drinking water in Cordoba, Argentina. Int. J. Epidemiol 27:561569.

[11] NRC, 2001. National Research Council. Arsenic in Drinking Water: 2001 Update. Washington, DC: National Academy Press

[12] Smith, A.H., Lingas, \& E.O., Rahman, M. 2000. Contamination of drinking water by arsenic in Bangladesh: A public health emergency. Bull WHO 78(9):1093-1103.

[13] Rahman M, Tondel M, Ahmad SA, \& Axelson 0.1998. Diabetes mellitus associated with arsenic exposure in Bangladesh. Am J Epidemiol 148:198-203.

[14] Longnecker MP, \& Daniels JL. 2001. Environmental contaminants as etiologic factors for diabetes. Environ Health Perspect 109(suppl 61:871876.

[15] Tseng CH, Tseng CP, Chiou HY, Hsueh YM, Chong CK, \& Chen CJ. 2002, Epidemiologic evidence of diabetogenic effect of arsenic. Toxicol Lett 133:69-76.

[16] Zierold KM, Knobeloch L, \& Anderson H. 2004. Prevalence of chronic diseases in adults e> posed to arsenic-contaminated drinking water. Am J Public health 94:1936-1937.

[17] NIH, 2007. National Institute of Health. Arsenic compound improves survival of adults with uncommon form of leukemia. ProQuest document ID:1201354551. Accessed February 13, 2007

[18] USEPA, 2003. United States Environmental Protection Agency. Technical summary of information available on the bioaccumulation of arsenic in aquatic organisms. EPA-822-R-03-032. Office of science and Technology $\&$ Office of water. Washington, D.C. USA.

[19] Holguín, C., Rubio, A.H., Olave, M.E., Saucedo, T, R., Gutiérrez, M., \& Bautista, M.R. 2006. Calidad del agua del Río Conchos en la región de Ojinaga, Chihuahua: Parámetros fisicoquímicos, metales y metaloides. Universidad y Ciencia 22(1): 51-63.

[20] Gutiérrez, M., \& Borrego, P. 1999. Water quality assessment of the rio conchos, Chihuahua, Mexico. Environmental International 25(5): 573-583

[21] NOM, 1981. Norma Oficial Mexicana. Norma NMX-AA-051-SCFI-1981. Análisis de agua-determinación de metales, método espectrofotométrico de absorción atómica

[22] Robinson, L., T. Sinks, A. Smith, M. Smith, M. Guinan, R. Todd, L. Brown, \& B. Dudding, 2001. Acute Lymphoblastic (Lymphocytic) Leukemia - Review and Recommendations of the Expert Panel. Nevada State Health Division.

[23] Steinmaus, C., Lu, M., Todd, R.L. \& Smith, A.H. 2004. Probability Estimates for the Unique Childhood Leukemia Cluster in Fallon, Nevada, 
and Risks Near Other U.S. Military Aviation Facilities. Environmental Health Perspectives 112(6):766-771.

[24] Lacayo, M.J., Cruz, A., Calero, S., Lacayo, J., \& fomsgaard, I. 1992. Total arsenic in water, fish and sediments from Lake Xolotlan, Managua, Nicaragua. Bull. Environ. Contam. Toxicol. 49:463-470

[25] Eisler, R. 1994. A review of arsenic hazards to plants and animals with emphasis on fishery and wildlife resources. In: Arsenic in the environment, Part II: Human health and ecosystem effects. J.O. Nriagu Ed. John Wiley \& Sons, N.Y. 185-259.

[26] Cantu, R., Stacell, M., \& Webb, M. 1991. Observation of abnormalities in largemouth bass fry exposed to arsenic contaminated water. Texas Parks and Wildlife Department. Austin, Texas, USA.

[27] USEPA, 1980. United States Environmental Protection Agency. Ambient Water Quality Criteria for arsenic. EPA 440/5-80-021. Office of water regulations and Standards. Washington, DC, USA. Available at: www.epa.gov/ost/pc/ambientwqc/arsenic80.pdf

[28] Kelly, M.E. 2001. El Rio Conchos: Un informe preliminary. Texas Center for policy studies. Marzo 2001. Austin, Texas, USA. 